\title{
A BizAlom SZövete
}

\author{
TÓTH-PJECZKA KATALIN
}

ELTE PPK Neveléstudományi Doktori Iskola

Dimitri Van Maele, Patrick B. Forsyth \& Mieke Van Houtte (eds): Trust and School Life: The Role of Trust for Learning, Teaching, Leading, and Bridging. Dordrecht, New York (NY), 2014. Springer Verlag. viii + 352 p. ISBN 978-94-017-8014-8 (eBook)

A 15 tanulmányt magában foglaló kötet széles nemzetközi kutatói kooperáció eredményeként született. Belga és amerikai szerkesztői, a bizalom oktatási intézmények szervezeti működésében betöltött szerepét tanulmányozó amerikai kutatócsoportok eredményeit és nyomvonalát követve, belga és holland kutatásokat egybegyüjtve, szisztematikusan járják körül a bizalom iskolai megjelenésének témáját.

Mivel a neveléstudományi kutatások közül, az eredményes oktatás érdekében, egyre több foglalkozik az iskolai kollektíva építésének, az iskola szervezeti müködésének vizsgálatával, nem megkerülhető az ezek alapját képező kollektív és egyéni bizalom kérdésköre sem. A közös célokért végzett közös munka megalapozójának, a bizalom jelenségének mélyebb megismerése az iskola kontextusában az eredményesebb oktatást célzó fejlesztő erőfeszítések egyik tartóoszlopa.

Habár a bizalom a társadalom múködésének alapját képező jelenség (Durkheimig visszamenőleg az egyik legrégebb óta taglalt szociológiai téma), a tágabb társadalmi vizsgálatok eredményei nem feltétlenül vonatkoztathatók közvetlenül az iskolára. A bizalom kontextusspecifikussága arra készteti a neveléstudományt, hogy saját közegében, az iskola szervezeti kontextusában is megvizsgálja a jelenséget. Annál is in- kább, mert a bizalom sűrű szövésű anyag, s az oktatásban más mintázatú, más erősségű textúrát hozhat létre, mint egyéb rendszerekben. Vagy mégsem?

A kötet első, nagyobb kiterjedésű tanulmánya tulajdonképpen egy bevezetés a bizalom neveléstudományi szakirodalmába. Rálátást ad a bizalom szövetének egészére, de a szálakat külön is vizsgálja. Röviden áttekinti a definíciókat, a kutatási fókuszokat $\mathrm{s}$ a jelenség néhány alapvető aspektusát, mint például a reciprocitást, a megbízhatóság összetevőit, a bizalom előzményeit. Felvázolja az iskola szervezetében megjelenő elemzési szinteket az egyéntől a csoporton át az iskolarendszer egészéig. Szót ejt a bizalommal összefüggésben a szocioökonómiai háttér jelentőségéről, a közös etnikai háttér bizalomképző erejéről, a szaktárgyakon alapuló osztályszervezési tényezők hatásáról, az iskola strukturális sajátosságairól, a tanulásközpontú iskolai kultúra hatásáról, a tanári szerepfunkciókról és a bizalomnak a tanulók szociális integrációjára gyakorolt hatásáról. A témának ez az étvágykeltő hatású terítéke jól megalapozza a könyv következő 14, többségében kvantitatív kutatásokat ismertető tanulmányát.

Az elméleti bevezetés után a kötet, négy fejezetben, a vizsgálódás főbb fókuszterületeit mutatja be: a bizalom szerepét a tanulásban, a tanításban, az iskolai veze- 
tésben, illetve az iskola falain kívüli kapcsolatokban.

$\mathrm{A} z$ első fejezet a tanulás és az iskolai szervezetben megjelenő bizalom összefüggéseit négy aspektusból, négy külön tanulmányban közelíti meg. Először egy, a tanári bizalom tanulói eredményességre gyakorolt hatásával foglalkozó kutatásról olvashatunk, amely egy középiskolai fejlesztő program (CAP - College Ambition Program) jelenleg is folyó hatásvizsgálata, és a tanulói eredményességet a továbbtanulás fonalán ragadja meg, rávilágítva a bizalom szerepére az iskolai eredményességet támogató társas viszonyok alakításában. A program sajátosságát képező kollektív diákmentorságról és annak a bizalomépítésben játszott szerepéről is képet kaphat, aki belemerül Barbara Schneidernek és kutatócsapatának tanulmányába.

A második empirikus kutatás a bizalom interkonnektivitását járja körül kimutatva, hogy egy szervezetre (pl. iskolára) jellemző bizalmi szint összefüggésben van azzal a bizalommal, amelyet a diákok és a szülők mutatnak az iskola és a tanárok felé. Az egymásra ható, összekapcsolt bizalmi szintek szignifikáns összefüggést mutatnak a tanulói teljesítménnyel. TschannenMoran kutatási eredményei aláhúzzák a bizalom témájának jelentőségét, és morális imperatívuszként továbbgondolásra ösztönzik a neveléstudomány aktorait. A tanulmány a kötet egyik legjelentősebb írásának tünik, az egyik meghatározó alapfonalnak a bizalom szövetében.

A fejezetben tájékozódhatunk még a szervezet előrejelző képessége és az intézményvezetőbe vetett bizalom összefüggéseiről, a fejezet utolsó tanulmányában pedig a tanárok igazgatóba vetett bizalmának kérdése már a megbízhatóság komponenseihez, a bizalom faktorális modelljéhez vezeti az olvasót. Vajon milyen tényezők hatnak közvetlenül a megbízhatóságra? Ha elolvassuk Makiewicz és Mitchell írá- sát, árnyalt választ kapunk erre a kérdésre. A Mayer-féle bizalommodell ${ }^{1}$ faktorainak (képesség, jóindulat, integritás) elsőrendűségét a szerzőpáros kutatása is igazolta, a tanárok bizalmi hajlandósága és a megbízhatóság közötti összefüggés azonban a jóindulat faktor esetén megfordul. Tovább színesíti a modellt az interakciók gyakorisága és a megbízhatóság/észlelés között kimutatott összefüggés, amelynek ok-okozatisága azonban még nem tisztázott.

A kötet második fejezete a tanításra fókuszál, pontosabban azokra az összefüggésekre, amelyek a szervezeten belül megjelenő bizalom és a tanítás egymásra hatását mutatják. Vajon mit tudhatunk meg a standardokra épülő elszámoltathatóság és a bizalmi szint kapcsolatáról? Hogyan hat az elszámoltathatóság a kiégésre? A. G. Dworkin és P. F. Tobe longitudinális kutatása elgondolkodtató összefüggéseket tár fel, rámutatva arra, hogy a büntetést hangsúlyozó elszámoltató rendszer rombolja az iskolán belüli bizalmat, és erősíti a tanárok kiégését. A példa amerikai ugyan, de indokot szolgáltathat arra, hogy elgondolkodjunk a hazai helyzet alakulásáról.

A kötet egyetlen kvalitatív kutatása a bizalom és a kollaboráció viszonyát mutatja be egy, a szervezetbe ágyazott tanuló szakmai közösségekről szóló esettanulmányban. A Pamela R. Hallam vezette amerikai kutatócsoport munkája alátámasztja a korábbi szakirodalmi eredményeket. Bizalom ott alakul ki, ahol az emberek, a gyakori informális társas kapcsolatoknak köszönhetően, jóindulatot, őszinteséget, nyitottságot, saját kompetenciát és megbízhatóságot mutatnak egymás felé. Ennek fontosságát a vizsgálat (éppenséggel egy toxikus intézményi közegben folytatott kutatás) azzal is alátámasztotta, hogy

\footnotetext{
1 Mayer, R. C., Davis, J. H. \& Schoorman, F. D. (1995) An Integrative Model of Organizational Trust. Academy of Management Review, Vol. 20. pp. 709-734.
} 
a bizalom nem intézményi szinten, hanem az egymással szakmai tanulóközösségben tevékenykedő tanárok között jött létre. Ott viszont mind a kapcsolati bizalom, mind az egymás kompetenciájába fektetett bizalom erősödését regisztrálták.

Talán a kötet felépítésében sem véletlen, hogy ez a tanulmány középtájon helyezkedik el, s mint a címe is mutatja, olyan mélyfúrást ismerhetünk meg belőle, amely a bizalom nulladik szintjét tárja fel. Vagy, hogy egy korábbi képünkkel éljünk, vele a bizalom szövetének alapanyagához, a fö fonalhoz értünk.

A tanárok tanulókba vetett bizalma és az iskola szervezeti kontextusa közötti összefüggést vizsgálja a kötet két szerkesztőjének kvantitatív tanulmánya. A flamand iskolákban végzett nagymintás kérdőíves kutatás összefüggést talált a tanárok tanulókba vetett bizalma és az iskola szervezeti jellegzetességei (pl. mérete vagy tanulói összetétele) között.

Mentorálás, bizalom és tanári hatékonyság a címe Serafino M. Celano és Roxanne M. Mitchell kevert módszerü kutatásának. Együtt jár-e a mentorált tanár mentorába vetett bizalma a személyes hatékonysággal? Melyek azok a programkomponensek, amelyek növelik a tanár mentor iránti bizalmát? Nemcsak ezekre a kérdésekre kapunk választ, de a kutatás eredményei azt is megmutatják, hogy a mentorprogram strukturáltsága növeli a mentorba vetett bizalom valószínűségét. Ami útmutatóul szolgálhat mentorprogramok fejlesztéséhez.

A harmadik fejezet a vezetés és bizalom kapcsolatát teszi górcső alá. Az amerikai Success For All programjához kapcsolódóan végzett nagymintás kutatás, amely az iskolai fejlesztőprogram hatását vizsgálta, az ellenőrző funkcióra összpontosítva, nem talált pozitív változást a tanárok egymás iránti bizalma tekintetében. Nem ez az első olyan eredmény, amely az ellen- őrzés és bizalom kapcsolatának kérdéskörét legalábbis vitatémaként teszi a szakma asztalára.

Page A. Smith és Adrian A. Flores kutatása bizonyítja, hogy a vezetői befolyás képes előrejelezni a szervezetben uralkodó bizalmi szintet. Ez annak ellenére így van, hogy a vezetői befolyásnak a tanárok közötti és a kliensek iránti bizalomra nincs közvetlen hatása. A tanulmány szerzői felhívják a figyelmet a vezetői befolyás jelentőségére a reformok intézményi implementációjában, s hangsúlyozzák a befolyással járó etikai felelősséget is.

A kötet szerintem egyik legérdekesebb kutatása is ebbe, a vezetésre fókuszáló blokkba tartozik. Nienke M. Moolenaar, Sjoerd Karsten, Peter J. C. Sleegers és Alan J. Daly munkája a szociális tőke elméletére épít, a tanuló szakmai közösségek bizalomépülésére fókuszál, és a szociális hálózat jellegzetességeinek és a bizalom alakulásának összefüggéseit boncolgatja. Nagymintás vizsgálatuk holland általános iskolák többszintű elemzésére épült, egyrészt szervezeti szinten, másrészt tanári szinten vizsgálták, hogy milyen összefüggés fedezhető fel a bizalom és a kapcsolati háló között. Szociálishálózat-elemző vizsgálatuk eredményei szerint egyéni szinten szignifikáns összefüggés van a szociális hálózat sűrűsége és a bizalmi szint között, ugyanez az iskolai szervezet szintjén nem volt kimutatható. Ugyanakkor felhívják a figyelmet arra az általuk a szociális háló sötét oldalának nevezett jelenségre, miszerint a kétoldalú kapcsolatok uralma a szervezeten belül a kollektív bizalmi szintre inkább negatív hatással bír. A klikkesedésnek ez a külön válfaja veszélyzóna mind a szervezeti bizalomépítés, mind a folyamatos szakmai fejlődést célzó tanári együttműködés szempontjából. A kutatócsoport felhívja a figyelmet arra, hogy fontos lenne több ismeretet szerezni a bizalom épülésének ar- 
ról a természetéről, amely a szociális háló alakulásának folyamatában rejlik. Vagyis még mélyebb fúrásokra ösztönzik a kutatótársadalmat.

$\mathrm{A} z$ utolsó, negyedik fejezet a hídképzést, a külső kapcsolatok építésének bizalommal kapcsolatos összefüggéseit vizsgálja. Az iskolai bizalom szövetének széléhez érve, a külső kapcsolódások zárják a textúrát. Az Alan J. Daly és munkatársai által folytatott, intézményvezetőket vizsgáló kutatás az innovációs klíma és a bizalom kapcsolódási pontjaira mutat rá. A szerzők hangsúlyozzák az igazgatók szerepét az iskolai eredményesség javítását célul kitűző reformok implementációjában, és a vezetők külső szakmai kapcsolatainak felértékelődésére hívják fel a figyelmet. Bemutatják, hogyan hat a vezetők más igazgatókkal való kapcsolatára és ezáltal a tanácsadáson keresztül történő támogatásra az innovatív szemlélet és a bizalom jelenléte. Szót ejtenek arról is, hogyan hat a vezetésben töltött évek száma a kollégákhoz való közelségre s ezáltal a bizalmi viszony alakulására is.

A szakpolitikai döntéshozatal sok esetben, idö- és struktúrahiányra hivatkozva, átlép a tényekre alapozás procedúráján. $\mathrm{A} z$ adatalapú döntéshozatal feltétele, hogy a szakpolitikai irányítók bizalmat adjanak a kutatások eredményeinek. Ugyanakkor mintha a tudományos tényfeltárások sem minden esetben tudnának becsatornázódni a megfelelő platformokra. Ezt a problémakört vizsgálta Julie Reed Kochanek és Matthew Clifford, akik azt találták, hogy az amerikai oktatási rendszerben (is) a személyes bizalmi kapcsolatok képezik azokat a csatornákat, amelyeken keresztül a tudományos eredmények a döntéshozatal asztalára, a figyelembe vett tények közé bekerülhetnek.

A kötet utolsó tanulmánya a tanároknak a folyamatos szakmai fejlődésüket segítő tudásforrásokba vetett bizalmának kérdésével foglalkozik. Ez az összehasonlító esettanulmány a svéd és a német oktatási rendszerben megjelenő tudásforrások megbízhatóságára vonatkozó tanári percepciót vizsgálta, és megállapította, hogy a svéd tanárok inkább receptív, nyitott és bizalomteli alapállással közelítenek a tudásforrásokhoz, míg a német tanároknál a forrás megbízhatóságának kérdése áll a középpontban. A szerző, Wieland Wermke, hangsúlyozza az oktatási rendszer szintjén megjelenő bizalom kulturális beágyazottságát, írásából egyfajta történelmi távlatú áttekintést is kapunk a vizsgált oktatási rendszerekre ható kultúrtörténeti folyamatokról.

A kötet utolsó előtti tanulmányában, ahogy korábban már említettem, az amerikai oktatási körzetekre vonatkoztatott szakpolitikai kapcsolatok s azok bizalmi aspektusa kapott hangsúlyt. Ennél is tágabb rendszerszintre tekint az előbbi (utolsó) tanulmány, amely a német és a svéd oktatási rendszer sajátosságait hasonlította össze a tanárok tudásforrásra irányuló bizalmának aspektusából. Ám a rendszerszintnek ez még mindig nem a legtágabb vetülete. A kontextuális jelleghez hozzátartozik az oktatási rendszert körülölelő egész társadalom bizalmi állapota. Valószínűleg ez a téma olyan közegekben kevésbé hangsúlyos, ahol a kollektív kapacitásfejlesztésben nem látványos akadályozó tényező ennek a szintnek az értékdeficites állapota. A mi társadalmunkban, ahol történelmi okokra visszavezethetően, a téma megkerülhetetlen aspektusa az össztársadalmi szintű bizalmi deficit, egy hasonló kötetben bizonyára ez a kérdés is hangsúlyozott helyet kapna.

A könyv első ránézésre világos, szépen strukturált építménye a mélyebb olvasás során megkérdőjeleződhet, hiszen például a tanulásblokkba elhelyezett ötödik tanulmány inkább a harmadik fejezethez, 
a vezetés témaköréhez tesz hozzá kézzelfogható eredményeket. Több példát is találhatnánk arra, hogy az iskolai szervezetek komplex rendszeréhez hasonlóan maga a bizalom is olyan összetett jelenség, amelynek sokdimenziós meghatározottságát, felépülésének sokszínűségét nem könnyű szétszálazni.
Mégis (vagy éppen ezért) érdekfeszítő tevékenység közelről - jelen esetben, mondjuk, inkább a túlnyomó többségében nagymintás kutatások távolságából - megvizsgálni, miként képezi egy-egy szál a bizalom szövetének mintázatát, vagy feltünés nélküli alapot biztosítva, hogyan válik a szövet összetartó erejévé.

A cikk a Creative Commons Attribution 4.0 International License (https://creativecommons.org/licenses/ by/4.0/) feltételei szerint publikált Open Access közlemény, melynek szellemében a cikk bármilyen médiumban szabadon felhasználható, megosztható és újraközölhető, feltéve, hogy az eredeti szerző és a közlés helye, illetve a CC License linkje és az esetlegesen végrehajtott módosítások feltüntetésre kerülnek. (SID_1) 